\title{
現場だより
}

\section{東京工業大学 像情報工学研究施設}

東京工業大学像情報工学研究施設 小門宏

\section{1. 生い立ちについて}

本研究施設* の起源は 20 数年前にさかのぼる. よう やくトランジスタの国産化に成功した頃である. 同時期 の米国では, 電子写真, 静電記録などエレクトロニクス 之結んだ記録・複製技術が摇らん期を脱しつつあった。 米国生まれのとの新技術が日本の産業生長にも大きな影 響をむつであろうとの 1 つの判断**が示され，昭和 29 年, 東京工業大学は「印刷技術研究施設」一本研究施設 の前身一を付置させるととになった，当時，新分野を表 わすに適当な名前はまだなかった。

ただ 1 人で着任した井上英一教授（当時助教授）は, 上述の設立の背景を知らされていなかったにもかかわら ず, 独自の判断加電子写真の研究を始めた. これは幸 運というべきであった．研究がすすむにつれ，とのテー マは当初の予想をはるかに超える工学的意味を明らかに しはじめた。電子写真を単に複製技術に限定せず，「情 報の流通過程における未踏技術開拓」の先がけとしてと らえ，さらに「情報が形を変える過程」そのものに注目 する立場を選んだ井上教授の考え方は, その後の研究施 設の在り方に決定的な影響を与えた。.ての分野が一般の 関心をよびはじめた昭和 39 年, 研究施設名は「印写工 学研究施設」と変った。信号を「印」, 変換・伝達を 「写」と表わす呼び名である. 昭和 41 年々 45 年化研究 組織が拡充され, 以来今日まで 3 部門構成で運営されて

表 1 研究組織と担当者 (51 年 6 月日現在)

\begin{tabular}{|c|c|c|c|c|c|}
\hline 部 門 名 & 教 & 授 & 助教授 & 助手 & 技官 \\
\hline 情 報 記 録 & 井上 & 英一 & 安居 院猛 & 2 & 1 \\
\hline 像 情 報 解 析 & 辻内 & 順平 & 柊元 宏 & 2 & 1 \\
\hline 像情報システム & 小門 & 宏 & (選考中)* & $1^{* *}$ & 1 \\
\hline
\end{tabular}

* 昭和 51 年 3 月まで池田光男氏が在任し, 視覚関係の研究を行ってい たが, 総合理工学研究科教授 (大学院担当専任) に昇任, 転出された. ** 定員 2 名のところ 1 名欠員.

* 国立大学では付置研究所の設置基準に該当しない研究機関を研究施 設と呼んでいる.

** 提案者不明. 一説に GHQ (昭和 27 年解散) 関係者という. 設立 の真意さえ，受け入れ側に正確て伝えられていなかったらしい。

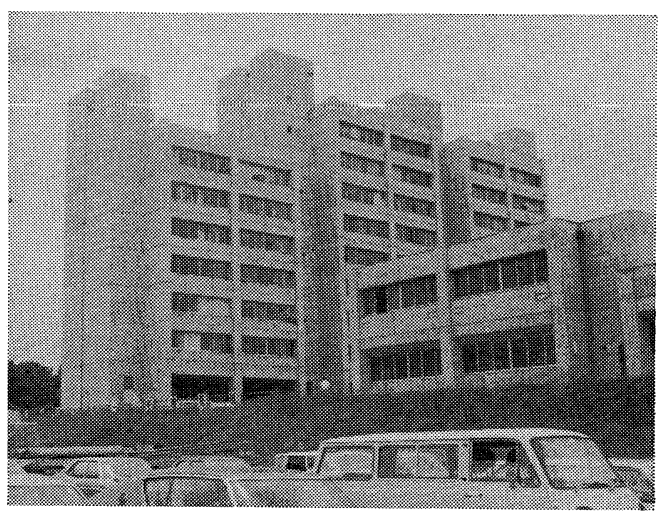

写真 1 東京工業大学工学部付属, 像情報工学研究施設 は, 横浜郊外, 東名高速道路の横浜インター近 くに位置している. 写真の左側 7 階建部分の 2 〜 5 階が研究室の主な部分である. 現在キャン パス建設中のため工事用の車や資材が見られる が， 3 年ぐらいの間に完成する予定である.

いる (表 1 参照)。現在の名称に改められたのは昭和 49 年で，旧称が「印刷＋写真」の誤解を受けやすいとの理 由からである。

昭和 50 年 9 月, 東京工業大学の方針一研究所群を中 心に別キャンパスに新構想の大学院を組織する一にした がって, 研究施設も目黒区大岡山の地を去り, 緑風さわ やかな横浜市緑区長津田町（田園都市線すずかけ台駅か ら徒歩 5 分）に移って日夜研究に精を出している.

\section{2. 研究活動について}

像情報工学は, 画像をはじめ, 音像から生産情報像 （たとえば IC 生産工程におけるマスクのような加工指 令像）にいたるすべての「表現された情報（像, image)」 の検知，計測，記録，蓄積，表示，再生，複製，認識， 伝達，処理などの技術に関する学問である.コンピュー ターによる情報処理が頭脳の肩代わりであるならば，像 情報工学は人間の感覚や手足の働きの代行を目標として いる．両者は，情報という名の車の両輪である.

像情報工学が多くの学問基盤を総合して成り立つとと 
表 2 各研究室における現在の主な研究テーマ

\begin{tabular}{|c|c|}
\hline $\begin{array}{l}\text { 井 } \\
\text { 上 } \\
\text { 研 } \\
\text { 究 } \\
\text { 室 }\end{array}$ & $\begin{array}{l}\text { 1. 銀-カルコゲナイドガラス層間の光ドーピング現象 } \\
\text { 利用の光センサーの特性. 2. 酸化亜鉛-樹脂系その他 } \\
\text { での可消去性光導電メモリーとその電子印刷マスター } \\
\text { への応用. 3. フラッシュまたはレーザー露光で使う } \\
\text { 感熱記録材料. } 4 \text {. 多孔性フィルムを用いるX線電子 } \\
\text { 写真システム, など情報の記憶, 記録または表示に関 } \\
\text { 係した分野. }\end{array}$ \\
\hline $\begin{array}{l}\text { 安 } \\
\text { 居 } \\
\text { 院 } \\
\text { 研 } \\
\text { 究 } \\
\text { 室 }\end{array}$ & 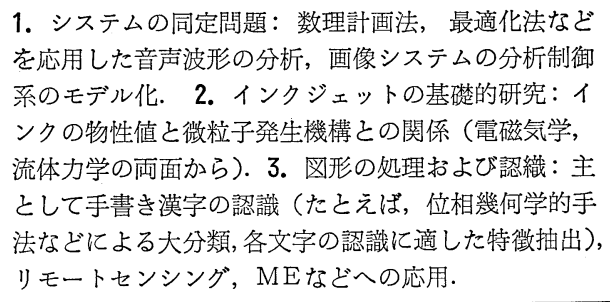 \\
\hline $\begin{array}{l}\text { 过 } \\
\text { 内 } \\
\text { 研 } \\
\text { 究 } \\
\text { 室 }\end{array}$ & $\begin{array}{l}\text { 1. 光計測执よび光情報処理： コヒーレント光による } \\
\text { 振動測定, 太陽電波干渉計の実時間信号処理. 2. ホ } \\
\text { ログラフィー：サーモプラスチックホログラム記録材 } \\
\text { 料, 音響ホログラフィーによる機械騒音源の探査, ホ } \\
\text { ログラフーによる } 3 \text { 次元ディスプレイ. 3. 画像処 } \\
\text { 理: 不鮮明像の鮮明化, 光学的ノンリニアフィルタリ } \\
\text { ング. }\end{array}$ \\
\hline $\begin{array}{l}\text { 柊 } \\
\text { 元 } \\
\text { 究 } \\
\text { 室 }\end{array}$ & $\begin{array}{l}\text { 1. 半導体中の欠陥のキャラクタリゼーション. } 2 . \\
\text { II-VI族化合物の接合特性. 3. 青色発光ダイオード. } \\
\text { 4. カルコパイライト型化合物の光電物性. 5. 青色螢 } \\
\text { 光体, など撮像や像表示に関連をむつ螢光体や半導体 } \\
\text { 光電材料の基礎・応用研究. }\end{array}$ \\
\hline $\begin{array}{l}\text { 小 } \\
\text { 門 } \\
\text { 研 } \\
\text { 究 } \\
\text { 室 }\end{array}$ & $\begin{array}{l}\text { 1. 光電導体から絶縁体への光電子注入とその画像記 } \\
\text { 録への応用. 2. 固体電解質材料の探索と画像技術へ } \\
\text { の応用. 3. } 2 \text { 次電子放出現象の画像システムへの応 } \\
\text { 用. 4. 画像記録材料系の一般的特性の解析など, 新 } \\
\text { しい記録システムを目ざした材料系の開拓と基礎現象 } \\
\text { の検討. }\end{array}$ \\
\hline
\end{tabular}

を反映して, 本研究施設の構成員の出身も光学, 物性物 理学, 応用化学, 制御工学など多様である. 幸いにあ活 動力に恵まれた各研究者が，お互いに連絡を保ち，励ま し合いながら独自の研究に没頭できる雾囲気がある. 将
表 3 本研究施設で指導を受ける学生, 研究生 (51 年度)

\begin{tabular}{c|r|c|c}
\hline \hline 博士課 程 & 修士課程 & 学部 4 年次 & 研 究 生* \\
\hline 5 & $20(1)^{* *}$ & 3 & $16(2)^{* *}$ \\
\hline
\end{tabular}

* 主に実務経験者が 1 2 年, 再教育のため研究室で研究指導を受ける.

**（）内は外国人（暲国, 米国）留学者数で内数.

来とあとれを大切にしたいと考えている.

\section{3. 教育活動について}

本研究施設の構成員はまた総合理工学研究科*を併任 して物理情報工学専攻（昭和 47 年発足）の大学院学生 の教育にもあたっている. この専攻には, 数学系, 物理 系, 生物系, 化学系, 電気系, 機械系のいずれかの学科 を修得した学生が入学して, 学際的色彩の濃い物理情報 工学一物理的手法を中心とする情報処理一の専門知識を 学ぶと同時に, 各研究室に所属して研究のすすめ方を体 験する. 教官は全部で 16 名, 本研究施設の教官のほか, 岸源也, 池田光男, 田幸敏治の各教授, 木田拓郎, 上田 光宏，今井聖の各助教授を專任とし，さらに5 名の併任 教授，助教授が協力している. この専攻と，大岡山にあ る情報科学専攻および情報工学専攻を合わせると, 情報 関係の全分野が包含される。

\section{4. 将 来 構 想}

像情報工学纪関与る技術的関心の拡大と細分化は，予 想を上回る速さですすんでいる．それに応じて本研究施 設も将来 8〜10 部門程度に拡充して総合的な研究所に 発展させたいと願っている.さしあたって, 情報表示, 視覚情報, 像情報処理の 3 部門を補う構想をあってい る. 本研究施設に寄せられる多くの期待と激励に心から 感謝すると同時に，現状でそれらに十分お応えする態勢 に至らないことをお詫びしたい.

* 主に学際的分野に関わる学科の上に乗らない大学院組織で, 物理情報 工学専攻のほか, 電子システム専攻など 9 の専攻があり, 将来すべて 長津田地区で活動する. 